\title{
Remodelling Macroeconomic Trilemma and Central Bank Behaviour in Nigeria: A Markov-Switching Approach
}

Taofeek Olusola AYINDE ( $\sim$ olusolaat@gmail.com )

Fountain University

Abiodun S., BANKOLE

University of Ibadan

\section{Research}

Keywords: Financial Openness, Business Fluctuations, Monetary Independence, Markov Switching Regression, Central Bank Behaviour

Posted Date: September 8th, 2020

DOI: https://doi.org/10.21203/rs.3.rs-70015/v1

License: (c) (i) This work is licensed under a Creative Commons Attribution 4.0 International License.

Read Full License 


\title{
REMODELLING MACROECONOMIC TRILEMMA AND CENTRAL BANK \\ BEHAVIOUR IN NIGERIA: A MARKOV-SWITCHING APPROACH \\ Taofeek Olusola, AYINDE ${ }^{1}$ and Abiodun S., BANKOLE ${ }^{2}$
}

\begin{abstract}
This study investigates macroeconomic trilemma and Central Bank behavior in Nigeria. The period of investigation spans the quarterly period of 1981 - 2017. Upon the data stability condition of Zivot-Andrew unit-root test with structural breaks, the Markov Switching Dynamic Regression was employed as the technique of analysis. With a validated trilemma hypothesis, the study found that the trilemma constraints hold for the Nigerian economy but at the expense of the autonomy of the monetary authority. Being the policy variable of the Central Bank of Nigeria, the exchange rate was found to follow two regimes of fixed and managed-float regimes. The results also showed that political risk was found insensitive to the regimes of exchange rate while the foreign sector was considered as a moderating factor for the behavior of the monetary authority; irrespective of the exchange rate regime.
\end{abstract}

\section{KeyWords: Financial Openness, Business Fluctuations, Monetary Independence, Markov Switching Regression, Central Bank Behaviour. \\ JEL Classifications: F41, E32, E52, C22, E58.}

\footnotetext{
${ }^{1}$ Lecturer and Researcher, Department of Economics, Fountain University, P.M.B. 4491, Oke-Osun, Osogbo, Osun State, Nigeria. Correspondences: ayinde.taolu@gmail.com; olusolaat@gmail.com; ayinde.taofeek@fuo.edu.ng; Mobile: +234(0)7063357968

${ }^{2}$ Professor of Economics, Faculty of Economics and Management Sciences, University of Ibadan, Nigeria.
} 


\subsection{Introduction}

The idea of the classical (macroeconomic) trilemma is well rooted in theoretical exposition. It came with the realization that there are sets of macroeconomic objectives that requires trade-off for proper economic management. As a result, the interest rate has been identified as the single most important policy variable for the attainment of internal balance in the economy (see Fisher, 1930; McKinnon, 1973; Shaw, 1973; Phelps, 1967; Muth, 1961; Wicksell, 1936). However, the interest rate parity condition suggests that how independently the central bank would control for the domestic interest rate to achieve this internal balance is restricted by the behavior of the foreign interest rate in the base economy (see Masih, 2005). This has further implications on the economy's balance of payment position and the value of her domestic currency. Consequently, there would be exchange rate instability if the monetary authority independently determines the domestic interest rate and allows free flow of financial capital (Dooley, Folkert-Landau and Garber, 2013).

In order to stabilize the domestic currency and independently determine the domestic interest rate, the monetary authority would, therefore, have to embark on capital repression policy (see Gan, 2014; Kim and You, 2016). On the other hand, an economy that seeks to pursue financial openness policy alongside the stability of the exchange rate should be prepared to trade off the autonomy of its monetary policy. The monetary policy, then, becomes endogenously determined by the movement in the exchange rate (see Goh and McNown, 2015; Georgiadis and Mehl, 2015). It is this difficulty to simultaneously achieve these three policies of monetary autonomy, exchange rate stability and financial openness; as propounded by the duo of Mundell (1963) and Fleming (1962) that is known as the macroeconomic trilemma.

In Nigeria, available data show that the Nigerian economy has been characterized by increasing interest rate regimes for the period 1970 - 2016. In 1970, the prime lending rate was 7.0 percent and this rate was consistently maintained till 1974. Up till 1981, a single digit interest rate of 7.75 was maintained but since 1982, the economy has been on double digit interest rate hovering around 20.0 to 30.0 percent. At times where the domestic interest rate has exceeded the foreign interest rate, the outcomes have been increased net financial flows. This happened in the periods 1970 - 1974 and 2011 - 2015 with corresponding average net capital flows of N66.96Million and $\$ 1$ 1,946.175Million respectively. To complete the insights for macroeconomic trilemma, the 
domestic currency depreciated to $\$ 2.026$ in 1986 and exchanged for $\$ 193.28$ by the end of 2015. It is expected that the accumulation of external reserves should afford the economy to maintain a middle-ground position of the trilemma constraint (Aizenman and Ito, 2012). A period of foreign reserve accumulation occurred in Nigeria only between 2003 and 2008. The foreign reserve increased correspondingly from US\$10Million to US\$50Million.

Also, it is believed that the central bank faces both ex-ante and ex-post constraints to its independence. The former, which is the ex-ante constraint, is such that the central bank board is usually appointed by the political authorities. Being appointed by the political officeholders suggests that the independence of the monetary authority can be compromised. In fact, Smaghi (2007) posited that legal provisions are only necessary but not sufficient conditions to ensuring the independence of central bank. This position is of greater concern for developing economies where it is said that poor institution still largely exists. As such, the autonomy of its monetary policy strategies would be less circumspect. It implies that the functional independence of the central bank cannot be ascertained if the personal independence cannot be guaranteed; especially when monetary policies are used to achieve fiscal policy goals (Golomejic, 2011).

The latter; which is the ex-post constraint, is such that the central bank also plays the role of government's bank. With this, the central bank can be influenced to make some unpopular decisions to protect the interest of the government of the day, particularly to remain in office and even possibly embezzle public funds when providing interventions in certain capital projects or some special needs with the claim of fulfilling its avowed role of economic management. Also, the monetary authority can be compelled to embark on lowering the interest rate or even charge negative interest rate so as to obtain cheap or costless capital purely for political motives in the economy. In this vein, monetary policy becomes instrument of obtaining fiscal objectives either directly through imposition of inflation tax or indirectly, through a discriminate but favourable interest rate to government borrowings (Dooley and Isard, 1980; Bartolini and Drazen, 1997). It is this latter position that is known as the self-serving government view of financial repression enunciated in the writings of Alesina and Roubini (1992) and Nordhaus (1975).

Beckmann, Ademmer, Belke and Schweickert (2017) put it succinctly when they classified these ex-ante and ex-post constraints as the opportunistic business cycle and partisan business cycle 
theories, respectively. The authors, however, attributed developed economies, being the focus of their investigation, with partisan preferences. This was conditioned on the fact that these economies have strong institutions to dissuade opportunistic business cycles (Park, Buntaine and Buch, 2017). For a developing economy such as Nigeria, however, both the partisan preferences and the opportunistic business cycle views matter for the autonomy of the monetary authority. These two forms of political business cycles, which are constituted into issues of institution, can delimit the potency of its monetary policy strategies. Even though the Central Bank of Nigeria Act of 2007 seeks to set the monetary authority in Nigeria to be truly autonomous, the fact that the central bank governor and its board are being appointed by the executive indicates that it cannot be truly independent. It is the collection of these issues that makes it imperative that this study investigate the role of institution in the behaviour exhibited by the Central Bank of Nigeria when confronted with macroeconomic trilemma. In addition to this introductory section, Section 2.0 reviews extant literature while Section 3.0 sets forth the methodological framework for investigating macroeconomic trilemma and the behaviour of Central Bank of Nigeria. In Section 4.0, estimates for the specified models were obtained and findings were discussed while Section 5.0, being the last, provides conclusion and proffer policy suggestions.

\subsection{Literature Review}

The theoretical linkage among financial openness, exchange rate and monetary policies is anchored on the Mundell-Fleming framework and the Compensation thesis. The compensation thesis is predicated on an accounting framework of double entry principle. It illustrates sterilization effects by an automatic mechanism within a stock-flow accounting analysis. As a post-keynesian theory, the compensation thesis is anchored on the assumption that the supply of money is endogenous, demand-led and has a horizontal curve. There is a possibility of multiple natural rates of interest since the short-term interest rates are exogenous and set by the central bank. Within the compensation thesis, causality moves from credit to money aggregates to reserves, Inflation and output growth. The theory suggests that all sectors of the economy need buffers as adjustment factors.

On the contrary, the standard Keynesian view, which is enshrined in the Mundell-Fleming framework, suggests that the supply of money is exogenous and can be viewed as a vertical 
curve. Rates of interest are endogenous. In this case, there exists a natural rate of interest and causality runs from reserves or high-powered money to money and then to credit and excess money growth causes price inflation. The compensation thesis is an extension of the reflux principle evidenced in the earlier writings of Nurkse (1947), Kaldor (1980) among others. This theory was built on the weaknesses of the Mundell-Fleming model. The compensation thesis does not assume infinite asset substitution, whereas most Keynesian authors such as Mundell (1961) predicated their theory on infinite asset substitution (Levoie and Yan, 2004).

As a way of general overview, the empirical literature falls under three major strands. The first strand relates to those studies that tests for the validity of the trilemma hypothesis, the second strand examines its impacts on macroeconomic fundamentals while the third strand debated the adjustments in the methods and methodologies. The first and second categories relate to those studies that test for the trilemma hypothesis and further investigate for its impacts on macroeconomic fundamentals either as country-specific studies or as cross-country studies. Examples of empirical works in this strand include the studies of Cheng and Qian (2009); Sengupta and Cheung (2011); Aizenman and Ito (2012a, 2012b); Aizenman and Ito (2014); Hsing (2013); Jamilov (2013); Hadiwibowo and Komatsu (2011); Ihnatov and Capraru (2014); Georgiadis and Mehl (2015) among others.

The major results of these studies are that, with the accumulation of international reserves, emerging market economies are adopting policy choices that are converging to a 'middleground' position of the trilemma constraint since the past two decades. For industrialized developed economies; however, there has been more divergence of the triad policies with a combination of high exchange rate stability and financial openness being most prominent. This usually occurs at the expense of monetary independence; largely due to regional integrations among countries within the European Union. The common conclusion reached is that the trilemma hypothesis is still binding. More so, the convergence of the triad policies to a 'middleground' position was found to be a pre-condition for financial stability, but not for output stabilization, in developing as well as emerging economies. But generally, to stabilize the real sector, convergence policy must be complemented with high international reserve holdings. A condition not necessary for developed industrialized economies. 
The third category of the trilemma hypothesis literature are those studies that provided various alternative measures for the trilemma indexes and different methods of analyses and, then, ascertain whether it differs from the conclusion reached with the use of the seminal measures provided by Aizenman, Chinn and Ito (2008). These studies queried the very basic foundation of the trilemma hypothesis through the trilemma indexes computed by Aizeman et. al., (2008) and, then, argued that either one component or the other of the triad measures is fraught in error. The index measure that is mostly criticized is the measure of financial openness. Traditionally, there are two measures of capital account liberalisation; indicators for financial openness. These are de facto and de jure measures. The former measure is a market-based measure that includes both the price and quantity measures while the latter measure includes legal and/or political measures ${ }^{3}$. More so, the interest rate parity condition between countries has been employed in various studies $^{4}$. For the extent of financial integration, the popular Feldstein and Horioka (1980) remains largely prominent while later writers have strengthened the literature with additional measures ${ }^{5}$.

Also, the measure of monetary independence has not been without its criticisms ${ }^{6}$. It is the critique of these foundational measures that informed that other new measures as well as gauges were suggested in the empirical literature for testing the validity or otherwise of the trilemma hypothesis. Schularik and Ward (2015) suggested a wavelet analysis where oscillations and cyclical properties of financial variables were accounted for. The result obtained was found consistent with other alternative measures; including the trilemma index. Popper, Mandilaras and Bird (2013) and Mandilaras (2015) introduced new gauge of stability which was bounded and correspondingly non-Gaussian. The study found that the combination of fixed exchange rates and financial market openness is the most suitable arrangements for either low or high-income countries. This is a possibility for emerging economies, only under a regional financial arrangement as obtained by Aizenman and Ito (2012) for the case of industrialized economies under European Union.

\footnotetext{
${ }^{3}$ See Rizavi, Naqvi \& Rizvi (2011); Pasricha (2010); Chinn \& Ito (2008); Baele et. al., (2004)

${ }^{4}$ See Frankel, (1991); Haque \& Montiel (1991); Montiel (1994).

${ }^{5}$ Vo (2005); Quinn, Schindler \& Toyoda (2011); Yabara (2012)

${ }^{6}$ See Frankel, Schmukler \& Serven (2004); Shambaugh (2004); Reade \& Volz (2010).
} 
Although, there are some studies that have enriched the empirical literature, the objectives pursued by these recent studies are not only aggregated in this study, but this study still further extends the frontier of knowledge in areas not covered. For instance, Beckmann et. al., (2017) appeared to have enriched the empirical literature with the political economy coverage of the impossible trinity; the study was a cross-country study where the peculiarities of the political components of each country have been muddled up. Again, the study captured the political economy of the trilemma constraint as a form of partisan business cycles; distinct from opportunistic business cycle. However, this study incorporates both the opportunistic and partisan business cycles as this properly characterized institutional development in a developing economy such as Nigeria.

\subsection{Methodology}

\subsection{Theoretical Framework and Models Specifications}

A major contribution of this study is to modify and extend the basic Mundell-Fleming framework in such a way that both macroeconomic trilemma and financial trilemma would be nested together; both being the double trilemma facing an economy, and concomitantly, trace how it alters the behaviour of the central bank. Practically, the modification is that, within the framework of the classical (macroeconomic) trilemma, the assumption of perfect asset substitutions must be relaxed. Consequently, the condition of uncovered interest parity, which presupposes risk-neutral investors, is modified to include a risk premium. These modifications become imperative since there are imperfect asset substitutions in developing economy such as Nigeria. In fact, investors are usually risk-averse in developing economies due to innumerable uncertainties. More so, the uncovered interest parity (UIP) condition cannot be satisfied without the inclusion of a risk premium since empirical studies have not established strong evidence for the validity of the UIP condition; even in the long-run situation (Chinn and Meredith, 2004). An extension of the Mundell-Fleming framework is to account for the political economy of central bank behaviour in a developing economy such as Nigeria where the role of institution cannot be under-estimated. 
The basic Mundell-Fleming framework is anchored on five (5) major assumptions of risk-free arbitrage condition; imperfect competitive firms with constant domestic price level and elastic supply of domestic output; imperfect capital mobility; perfect asset substitutions and small country assumption that is not capable of influencing the global dynamics of prices and income. As presumed, an evaluation of these assumptions validates that there is imperfect capital mobility in Nigeria. Capital is imperfectly mobile in a developing economy such as Nigeria since cross border capital transactions are usually sequenced and movement of financial capital is often gradual (Bankole and Ayinde, 2014). Importantly, the Mundell-Fleming model contributes two main theoretical elements to the autarky framework of IS-LM. Firstly, there exists an extra output demand element to capture economic interaction with other economies of the world. This is the net export component of the real sector equilibrium. Secondly, there is uncovered interest parity (UIP) condition that is predicated on risk-neutral behaviour of investors. These two conditions are weighty.

The first contribution indicates that the balance of payment (BoP) equation would be included in obtaining the simultaneous equations that comprise set of endogenous and exogenous variables, thus, the name IS-LM-BP framework. The second condition suggests there is risk-free arbitrage where the ratio of the forward to the spot exchange rate will equate the interest rate differential between the two assets; measured in domestic currency. This is given as;

$e_{f_{t, t+k}}-e_{s_{t}}=\left(i_{t, k}-i_{t, k}^{*}\right)$

Where; $e_{s_{t}}$ is the exchange rate of domestic currency in terms of foreign currency at time $\mathrm{t}$ (spot rate); $e_{f_{t, t+k}}$ is the forward value of $e_{s_{t}}$ for a contract due in k periods in the future; $i_{t, k}$ is the kperiod return on domestic assets while $i_{t, k}^{*}$ is the corresponding return on the foreign assets. Equation (1) is the risk-free arbitrage condition. To the extent in which the investors are riskaverse, the forward rate differs from the spot rate at a risk premium given as $\varphi$. This is to compensate for the perceived riskiness of holding the domestic assets in terms of the foreign assets. The risk premium is defined as;

$\varphi_{t, t+k}=e_{f_{t, t+k}}-e_{s_{t, t+k}}^{*}$

Substituting equation (2) into (1) gives;

$e_{s_{t, t+k}}^{*}-e_{s_{t}}=\left(i_{t, k}-i_{t, k}^{*}\right)+\varphi_{t, t}$ 
$\Delta e_{s_{t, t+k}}^{*}=\left(i_{t, k}-i_{t, k}^{*}\right)-\varphi_{t, t}$

From equation (4), the uncovered interest parity (UIP) condition holds when the risk premium equals zero (i.e. $\varphi_{t, t+k}=0$ ) such that;

$\Delta e_{s_{t, t+k}}^{*}=\left(i_{t, k}-i_{t, k}^{*}\right)$

This implies that the expected change in the exchange rate from period $t$ to period $t+k$ equals the current interest rate differential. As such, the investors become risk-neutral between holding domestic assets or foreign assets. Including a rational expectation hypothesis as the market value of expected exchange rate is not observable. Then, we have;

$e_{s_{t, t+k}}^{r^{*}}=-e_{s_{t+k}}+\zeta_{t, t+k}$

Therefore, substituting equation (5) into (4) gives;

$\Delta e_{s_{t, t+k}}=\left(i_{t, k}-i_{t, k}^{*}\right)+\varphi_{t, t+k}+\zeta_{t, t+k}$

Under the risk-neutral condition of the investors, the last two terms are assumed orthogonal to the interest rate differential.

Relaxing the assumption of risk-neutral investors, however, we have an empirical model for uncovered interest parity condition with risk premium given as;

$\Delta e_{s_{t, t+k}}=\beta_{o}+\beta_{1}\left(i_{t, k}-i_{t, k}^{*}\right)+\zeta_{t, t+k}$

Where; a non-zero $\beta_{o}$ captures the risk premium component of the UIP condition.

This study is, therefore, anchored on the augmented Mundell-Fleming model. This model has four building blocks of goods market equilibrium, money market equilibrium, balance of payment equilibrium and the uncovered interest parity (UIP) condition. Equation (7) is the UIP condition with risk premium component and the goods market equilibrium is made up of:

$Y=C(Y-T)+I(i)+G+N X(Y, e)$

Where; $C$ is the consumption, $I$ is the level of investment, $G$ is the government expenditure; which is exogenously determined, $N X$ is the net export. The Mundell-Fleming framework presupposes that consumption is determined by the disposable income $(Y-T)$, investment is determined by the interest rate $(r)$ and the net export is a function of income $(Y)$ and the real 
exchange rate $(e)$. The $(e)$ measures the level of competitiveness given as $E \frac{P^{*}}{P}$. Where; $E$ is the nominal exchange rate and $\frac{P^{*}}{P}$ is the ratio of foreign price level to the domestic price level. The third equilibrium is the money market equilibrium given as;

$M^{d}=M^{s}$

$M^{d}$ is the demand for money while $M^{s}$ is money supply which is exogenously determined.

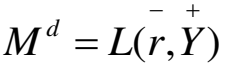

Equation (10) suggests that the demand for money is determined by both the interest rate and aggregate income in the economy.

Equating equations (9) and (10) yields;

$\frac{M}{P}=L(\vec{i}, \stackrel{+}{Y})$

Where; $\frac{M}{P}$ is the real money balances. However, the fact that there is interest rate differential implies that equation (11) becomes;

$\frac{M}{P}=L(\stackrel{-}{i}+\varphi \stackrel{+}{Y})$

On the condition that capital mobility is imperfect for a developing economy such as Nigeria, the balance of payment equation is non-zero and it is given as;

$B P=C A+K A$

Where; CA is the current account component while KA is the capital account component. Given that the current account captures the trade balance $(N X)$ and that the capital account being largely determined by a shift parameter $(k)$ and the interest rate differential of the returns on domestic asset and foreign asset; equation (13) becomes;

$B P=N X+\Upsilon\left(i-i^{*}\right)+k$

Equations (8), (12), (14) and (7) are four systems of equations that include the real sector (goods market) equilibrium, money market equilibrium, external sector equilibrium and the UIP condition respectively. These give a modified Mundell-Fleming model thus; 


$$
\begin{aligned}
& Y=C(Y-T)+I(i)+G+N X(Y, e) \\
& \frac{M}{P}=L(\bar{i}, \stackrel{+}{Y}) \\
& B P=N X+\Upsilon\left(i-i^{*}\right)+k \\
& \Delta e_{s_{t, t+k}}=\left(i_{t, k}-i_{t, k}^{*}\right)-\varphi_{t, t+k}+\zeta_{t, t+k}
\end{aligned}
$$

A solution to the simultaneous equations above would partition the variables into a set of exogenous variables $\left(p, p^{*}, i^{*}, \Delta e_{s_{t, t+k}}, \operatorname{EorM}_{s}\right)$ and a set of endogenous variables $\left(Y, i, M_{s}\right.$ orE $)$; depending on the exchange rate regime. E (nominal exchange rate) becomes the endogenous variable if the exchange rate regime is flexible. Then, $\mathrm{M}_{\mathrm{s}}$ (money supply) becomes an exogenous variable. $M_{\mathrm{s}}$ (money supply) is the endogenous variable if it is a fixed exchange rate regime and the $\mathrm{E}$ (nominal exchange rate) becomes an exogenous variable.

Alternatively, equation (15) is re-arranged such that the domestic interest rate becomes the subject of the formular for a single regression equation. This yields a behavioural model for this study, given thus;

$i=f\left(Y, \frac{M}{P}, N X, \pi\right)$

Equation (16) is the economic model for this study and it suggests that the domestic interest rate is a function of income, real money balances, net export and some control factors such as level of financial development.

Recall from equation (12) that $i=i^{*}+\varphi$. Therefore, equation (16) becomes;

$i^{*}+\varphi=f\left(Y, \frac{M}{P}, N X, \pi\right)$

Invoking the uncovered interest rate parity condition that interest rate differential must equal the expected proportionate change in the spot exchange rate between the time the investment is undertaken and the time it matures (future rates).

$$
\begin{gathered}
\varphi=\frac{e^{s}-e^{m}}{e^{s}} \ldots \\
i-i^{*}=\frac{e^{s}-e^{m}}{e^{s}}
\end{gathered}
$$

Where; $e^{s}$ is the expected spot exchange rate while $e^{m}$ is the expected exchange rate at maturity. 
Since $\varphi=i-i^{*}$, then, substitute equation (17) into (16) to have;

$$
\begin{aligned}
& i^{*}+i-i^{*}=f\left(Y, \frac{M}{P}, N X, \pi\right) \ldots \\
& i^{*}+\frac{e^{s}-e^{m}}{e^{s}}=f\left(Y, \frac{M}{P}, N X, \pi\right) \\
& \frac{e^{s}-e^{m}}{e^{s}}=f\left(Y, \frac{M}{P}, N X, \pi, i^{*}\right) \ldots
\end{aligned}
$$

With perfect foresight assumed, the expected change in exchange rate is taken as the actual change. Therefore, equation (20) becomes;

$$
\Delta e=f\left(Y, \frac{M}{P}, N X, \pi, i^{*}\right)
$$

Equation (21) is the functional model that relates to how the central bank behaves in the face of macroeconomic trilemma and the behavioural variable for the monetary authority is the changes in the exchange rate. It is important to note that money supply would no longer be exogenous but rather becomes endogenous in nature; especially for a developing economy such as Nigeria where the monetary authority seek to stabilize the exchange rate. As a result, the central bank sells domestic currency to buy foreign currency in order to avoid an appreciation and buys domestic currency to sell foreign currency in order to avoid depreciation.

\subsection{Framework for Markov Switching Dynamic Models}

Considering an unobserved states or regimes which is said to follow a Markov chain process (Quandt, 1972; Goldfeld and Quandt, 1973; Mills and Wang, 2006; Guidolin, 2011a; 2011b), the evolution of exchange rate can be modeled as a state-dependent intercept term for $k$ states;

$e_{t}=\psi_{s_{t}}+\phi e_{t-1}+\xi_{s} ; s_{t} \in\{0,1\}$

$e_{t}=\psi_{s_{t}}+\beta \sum_{t=1}^{3} X_{t}+Z_{t} \lambda_{s}+\xi_{s}$

Equation (22) is a Markov Switching Autoregression Model while equation (23) is a Markov Switching Dynamic Regression Model. The former has a fixed transition probability while the latter has a time-varying transition probability that is amenable to the changing form of the transition probability from one state to another; due to the dynamics of the explanatory variables. The explanatory variables include the triad-policy of exchange rate stability, financial integration 
and monetary independence; this gives the summation of the financial trilemma components. It has state-invariant coefficients $\beta$ while other variables that drive exchange rate are considered as control variables in equation (20) coupled with independently identically distributed random variable $\xi_{s}$ that follows a normal distribution with zero mean and $\delta_{s_{t}}^{2}$ state-dependent variance (equations 24 and 25). $\lambda_{s}$ is the state-dependent coefficients for the control variables.

$\xi_{t} \sim N\left(0, \delta_{s_{t}}^{2}\right)$

$\delta_{s_{t}}^{2}=\sum_{s=1}^{k} \delta_{s}^{2}, \sum_{s=1}^{k-1} \delta_{s}^{2}>0$

$\psi_{s_{t}}=\sum_{s=1}^{k} \psi_{s}$

Where; $\psi_{s_{t}}=\psi_{1}$ when $s_{t}=1, \psi_{s_{t}}=\psi_{2}$ when $s_{t}=2, \ldots$, and $\psi_{s_{t}}=\psi_{k}$ when $s_{t}=k$. The conditional density of $i_{t}$ is assumed to be dependent only on the realization of the current state $s_{t}$ and is given by $f\left(i_{t} \mid s_{t}=n, i_{t-1} ; \vartheta\right)$ where $\vartheta$ is a vector of parameters. There are $k$ conditional densities for $k$ states, and estimation of $\vartheta$ is performed by updating the conditional likelihood using a nonlinear filter. $s_{t}$ is an irreducible, aperiodic Markov chain starting from its ergodic distribution $\pi=\left(\pi, \ldots, \pi_{k}\right) ;-($ Hamilton, $1989 ; 1990)$. The probability distribution of the Markov Switching model is expected to follow a logistic distribution (Appendix 1; Hamilton, 1994; Chen and Shen, 2007 for modeling frameworks)

With a reflection of the dynamic interactions among the variables, the lags of exchange rates are also introduced as explanatory variables in equation (32) such that the methodological model, based on the Markov Switching framework, becomes;

$\Delta e_{t}=\psi_{s_{t}}+\alpha e_{t-i}+\beta \sum_{t=1}^{3} X_{t}+Z_{t} \lambda_{s}+\xi_{s}$

It should be noted that the number of lags of dependent variable, $i$, introduced depends on what is considered the optimum lag length. Substituting equation (18) into (27) yields the timevarying Markov-Switching model of the form

$$
\Delta e_{t}=\psi_{s_{t}}+\alpha \Delta e_{t-i}+\beta_{1} r g d p+\beta_{2} g m_{2}+\beta_{3} n x+\beta_{4} f \text { int } r+\beta_{5} \text { polit_risk }+\beta_{6} \Delta c p i+\xi_{s}
$$


Equation (33) is the methodological model for this study. It captures the Markov-Switching behaviour of the central bank when confronted with the double trilemma. The model is a timevarying form of the Markov-Switching model.

\subsection{Estimations and Discussion of Findings}

\subsection{Descriptive Statistics and Data Stability Conditions}

In order to obtain the statistical properties for the variables included for models specifications, the descriptive statistics among these variables were found appropriate. As detailed in Table 4.1, the change in the exchange rate $(\wedge e)$ has mean value of 5.95. This suggests that the exchange rate in Nigeria depreciated more for the period under consideration. This is an indication that there is presence of currency over-valuation with the skewness value of 8.57. The implication is that the naira positively deviates from the expected market value. This is supported by the standard deviation value of 28.19 that indicates that the domestic currency largely deviates from the expected value. Although, the kurtosis (being an atheoretical measure of normal distribution) value of 83.91 suggests that exchange rate movement in Nigeria is leptokurtic. That is, it is highly peaked with very thin tail. Also, the political risk variable (denoted as politrisk) shows that political risk in Nigeria is averagely very high as the mean value is below the 50 percent threshold. Specifically, it is 45.76 . The skewness value of 0.65 is an indication that political risk in Nigeria is positively skewed; implying that it escalated a little bit from the expected value. Also, the standard deviation value of 3.90 for political risk factor in Nigeria shows that the political risk in the country does not deviate substantially from the expected value. Both the kurtosis value of 2.69 and Jarque-bera statistics of 10.21 strongly lend credence to the normal distribution of political risk in the country for the period under review.

On the other hand, the growth of real gross domestic product (denoted as $\mathrm{rgdp}$ ) is averagely 1.21 but with -1.31 skewness value. This shows that economic growth in Nigeria has averagely been on a downswing and has skewed negatively from the expected value by 1.31 . This is an indication that economic growth in Nigeria has been grossly non-performing for the period under consideration. In addition, growths of money supply $\left(g m_{2}\right)$ also has similar behaviour with 5.71 
mean values. This indicates that price in Nigeria have been appreciably controlled as the average price index; caused by monetary growth, has not reached double digit

Table 1: Statistical Properties of the Variables

\begin{tabular}{|l|c|c|c|c|c|c|c|}
\hline Variables & Maximum & Minimum & Mean & Std. Dev. & Skewness & Kurtosis & $\begin{array}{c}\text { Jarcque- } \\
\text { Bera Stat. }\end{array}$ \\
\hline$\wedge e$ & 294.41 & -9.22 & 5.95 & 28.19 & 8.57 & 83.91 & $39045^{*}$ \\
\hline$c p i$ & 180.15 & 0.48 & 47.84 & 51.95 & 1.00 & 2.83 & $23.08^{*}$ \\
\hline forei_int $r$ & 18.87 & 3.11 & 7.41 & 3.24 & 0.78 & 4.16 & $21.66^{*}$ \\
\hline gm & 37.67 & -8.12 & 5.71 & 6.88 & 1.02 & 5.66 & $64.19^{*}$ \\
\hline$n x$ & 5734530 & -2086.68 & $625,882.8$ & 1029110 & 2.55 & 10.20 & $443.56^{*}$ \\
\hline$p o l i t r i s k$ & 54.33 & 38.46 & 45.76 & 3.90 & 0.65 & 2.69 & $10.21^{*}$ \\
\hline rgdp & 10.46 & -11.57 & 1.21 & 3.08 & -1.13 & 9.38 & $261.85^{*}$ \\
\hline
\end{tabular}

Source: Authors with Data Obtained from the Central Bank of Nigeria (CBN) Statistical Bulletin (2018)

In terms of data stability conditions, the test statistics for the unit-root and stationarity tests detailed in Table 2 suggests that some of the variables are unit-root as well as non-stationary at levels while some other variables are non-unit-root as well as stationary at levels. Particularly, the conditioning variable or the variable of interest - the change in the exchange rate $(\wedge e)-$ is non-unit-root and stationary at levels. The use of the Augmented Dickey Fuller (ADF) and the Phillip-Perron (PP) confirm the non-unit-root of the change in the exchange rate while the Kwiatkwoski-Phillips-Schmidt-Shin (KPSS) confirm its stationarity. This is so as the variable ( $\wedge e$ ) has test statistics of -10.923 and -10.928 that are greater than their values at the critical level; given as -3.478 for both, at the 1 percent level. As such the null hypothesis of unit-root is rejected; even at the 1 percent level of significance.

Other variables that are also stationary at the 1 percent level are growth of money supply $\left(g m_{2}\right)$ and the rate of inflation (inf $r$ ). The $g m_{2}$ have -12.863 and -12.781 as test statistics values for both $\mathrm{ADF}$ and PP; which are greater than their critical values at the 1 percent level. The inf $r$ have -2.916 and -8.390 as test statistic values for both ADF and PP that are greater than their 
critical values at the 5 percent levels. Hence, the null hypothesis of unit-root is also rejected. The stationarity test for these variables reinforces the submission on non-unit-root for these variables as the test statistics values for $\wedge e$ and $g m_{2}$ suggests that the null hypothesis of stationarity for the KPSS cannot be rejected at the 1 percent level of significance (Table 2)

Table 2: $\quad$ Unit Root and Stationarity Tests

\begin{tabular}{|l|c|c|c|c|c|c|}
\hline & \multicolumn{5}{|c|}{ Level } & \multicolumn{3}{c|}{ First Difference } \\
\hline VARIABLES & ADF & PP & KPSS & ADF & PP & KPSS \\
\hline$\wedge e$ & $-10.932^{*}$ & $-10.928^{*}$ & $0.189^{*}$ & - & - & - \\
forei_int $r$ & -2.725 & $-3.399^{* *}$ & 1.187 & $-4.254^{*}$ & - & 0.190 \\
gm $m_{2}$ & $-12.863^{*}$ & $-12.781^{*}$ & 0.193 & - & - & - \\
& -2.673 & $-21.797^{*}$ & 0.724 & $-21.583^{*}$ & - & $0.328^{*}$ \\
$r g d p$ & & & & & & \\
$n x$ & $-3.573^{*}$ & $-3.332^{* *}$ & 0.984 & - & - & $0.034^{*}$ \\
$\inf r$ & $-2.916^{*}$ & $-8.390^{*}$ & $0.403^{* *}$ & - & - & - \\
politrisk & $-1.559^{* *}$ & -2.042 & $0.193^{*}$ & $-4.596^{*}$ & $-4.471^{*}$ & - \\
\hline
\end{tabular}

Note: Unit-root and Stationarity tests are with constant but without deterministic trend. Lags are included with automatic and based on Schwarz info criteria. *,**, *** imply that the series is stationary at $1 \%, 5 \%$ and 10\% respectively. ADF, PP and KPSS represent Augmented Dickey-Fuller, Phillips-Perron and Kwiatkwoski-Phillips-Schmidt-Shin Unit Root and stationarity tests respectively. ADF: $1 \%=-3.478 ; 5 \%$ $=-2.882 ; 10 \%=-2.578 ;$ PP: $1 \%=-3.478 ; 5 \%=-2.882 ; 10 \%=-2.578 ;$ KPSS: $1 \%=0.739 ; 5 \%=0.463$; $10 \%=0.347$.

\subsubsection{Macroeconomic Trilemma and Central Bank Behaviour in Nigeria}

The behaviour of the central bank in the face of macroeconomic trilemma can be examined on the bases of how the monetary authority employs the use of monetary policy instruments to achieve an overall health of the economy with trade off of macroeconomic objectives; including economic growth (through increased investment) and balance of payment equilibrium (through interest rate differential and exchange rate stability). Also, the attainments of these macroeconomic fundamentals are to be examined in order to determine how they will alter the 
stability of monetary policy variables such as the interest rate and the exchange rate. The ex-ante behaviour relates to how the central bank uses the monetary policy instruments to achieve macroeconomic objectives while the ex-post behaviour indicates how the extent of attaining these macroeconomic objectives affect the stability of interest rate and exchange rate. Specifically, the ex-post behaviour is usually considered as the reaction function of the central bank (Siri, 2012). It is the combination of both the ex-ante behaviour and ex-post behaviour that summed up the behaviour of central bank in an economy.

Usually, the changes in the rate of interest in the economy are affected by the level of money supply. Basically, the level of money supply provides the direction for the rate of interest. Figure 1 implies that money supply has increased steadily since 1996:Q1 with negligible decline in the first quarters of 2009, 2014 and 2017. Expectedly, if these increases in money supply have been absorbed into the economy, the level of interest rate should decline and further stimulate investment opportunities. However, the rate of interest appeared not particularly affected by the changes in the supply of money (see Figure 2). During these periods, the reserve requirements of the deposit money banks in Nigeria remain stable until 2011Q1. While the increase in the reserve requirements is considered a contractionary monetary policy, the money supply still increased steadily. The implication is that other counteracting expansionary policy would have neutralized that effect (see Figure 1). A further implication of the foregoing is that even though the money supply is expected to be an endogenous variable in an economy such as Nigeria which operates a managed-float foreign exchange rate regime and sometimes fixed peg regime, money supply has been largely exogenously determined by the monetary authority. More so, the interest rate in Nigeria did not always moves with that of the foreign interest, indicated by the US interest rate (see Figure 2). By the simple interest rate parity condition and given a capital mobility condition, the domestic interest rate is expected to be at par with that of a referenced foreign interest rate. For the case of Nigeria, however, it is evident that this is not always the case. This further lends credence to the independence of monetary policy in Nigeria.

Nonetheless, the exogenous determination of money supply by the central bank of Nigeria has been carried out at discretion rather than sticking to rules. This is obvious from the graphical trend of both the targeted and actual money supply depicted in Figure 3. Except for the periods 
1996 - 1997, 2004, 2009, 2011 and 2018; the actual money supplied into the economy deviated from the targeted amount by the monetary authority throughout the periods $1985-2018$. For the period 1985 - 1990, there was no target earmarked by the central bank of Nigeria for its monetary aggregates. While the targeted money supply was relatively stable between 1996 and 2005, that actual money supplied is cyclical throughout. In whole, this suggests that the behaviour of the central bank towards money supply in Nigeria is discretional rather than being at a rule (see Figure 3). More importantly, a variable that can affect the level of broad money supply when endogenously determined is the movement in the level of exchange rate. For the periods 1981 - 1985 and 1993 - 1998, the rate at which the domestic currency (the Naira in this case) exchanges for a unit of foreign currency (the US\$ in this case) were relatively stable; this occurs for same the reason of fixed exchange rate regime but at different dimensions.

The period 1993 - 1998 was the height of military incursion in Nigeria where Nigeria operates a fixed exchange rate regime against the US Dollar but the period 1981 - 1985 was the period characterized by fixed peg of the naira to a weighted basket of currencies of Nigeria's major trading partners which are the US dollar, the British pound sterling, the German mark, the French franc, the Dutch guilder, the Swiss franc, and the Japanese yen. The exchange rate depreciates in the year 1999 to 2004; with marginal appreciation between 2005 and 2008 (see Figure 4). Due to the advent of democratic dispensation in the country, the foreign exchange was left to the dynamics of market forces; where government intervention was considerably negligible. The official rate hovers around 150 to 160 between 2009 and 2014 and witnessed a sharp increase in 2018. In tandem with the endogenous nature of the money supply under a fixed exchange rate regime, the value of money supply falls between 1993 and 1998. This implies that the monetary authority had to deplete the foreign reserve to defend the naira from being devalued, thus, led to the reduction in the amount of money injected into the economy during the period. Similarly, the actual money supply declines in 2015 following fixity of the exchange rate in 2014. For the period 2004 - 2008, the foreign reserve in Nigeria increased, declined in 2009 and remained low till 2010. By 2011, it increased again to its previous level in 2008 and remained stable till 2012. The foreign reserve fell freely in 2013 up till 2015; perhaps due to the fall in the demand for Nigeria's exportable oil in the international foreign market which snowballed into depreciation of her domestic currency (see Figure 5). By 2017, the foreign reserve has started building up 
again. It was because the free fall of the naira has to be prevented that the monetary authority subscribed to fixed exchange rate regime as against subjecting the currency to the dictates of the market forces.

\subsubsection{Policy Variables of Central Bank Behaviour in Nigeria}

Consequent upon the non-parity condition of the domestic interest rate in Nigeria to its foreign counterpart (see Figure 1), it becomes expedient to acknowledge that the exchange rate, therefore, becomes the policy variable of the monetary authority in Nigeria. This is because the exchange rate alters the direction of money supply in the economy and the supply of money, then, impacts on the domestic interest rate. This underscores the reason why the interest rate cannot be the policy variable. The interest rate is endogenously determined by the exchange rate. Again, the fact that the assumption of perfect capital mobility does not hold for a developing import-dependent economy such as Nigeria suggests that interest rate would be endogenously determined rather than being the variable for strategic monetary policy in the country. This is importantly so in that the monetary policy must review its interest rate from time to time to align the economy to the dynamics in the global marketplace.

\subsubsection{Political Risks and Central Bank Behaviour in Nigeria.}

In order to capture the political economy of central bank behaviour in Nigeria, this study considers the political risk factor as the most appropriate measure of institutional factor in the country. This is because it is believed that the central bank; being the government's bank, can do the biddings of public office holders and can be influenced to behave differently from what the economic situation demands; mainly for political reasons - like winning elections, perpetuating themselves in office, stepping down unpopular decisions due to ethnic, religious and cultural pressures and, even, pressures from opposition parties. The exegeses of these political factors tend to alter the behaviour of the central bank in a developing economy such as Nigeria. It is from the foregoing that the behaviour of the central bank in Nigeria is likely to be affected by political risks; even in the face of the macroeconomic trilemma.

Stemming from the foregoing, a cursory overview of political risks confronting Nigeria for the period (1981Q1 - 2015Q4) under review is highly imperative in this sub-section of the study. 
More so, how these political risks have influenced the direction of monetary policies in the country will be highlighted. As a decision rule, it is expected that the higher the sum total of the weight, the lower the risk and vice versa. For assessment purposes, a weighted sum less than 50 percent is considered very high risk; between $50-60$ percent is high risk; $60-70$ percent is moderate risk; $70-80$ percent is low risk while $80-100$ percent is very low risk. The trend in Figure 25 borders on political risks for the country and the behaviour of monetary policies during this period. These monetary policies are growth of money supply $\left(g m_{2}\right)$, the rate of interest ( int $r$ ) and the growth ratio of credit to the private sector to the GDP ( $c p s_{-} g d p_{-} g r w t$ ) - see Figure 6.

In Nigeria, there were just two episodes of political risks; an episode of very high political risk and the episode of high political risk. The former episode occurred from 1981Q1 - 1987Q2 and 2003Q3 - 2015Q4 while the latter episode occurred only between 1987Q3 - 2003Q2. For the episodes of very high political risks, the weighted sum of the political risk components were less than 50 percent benchmark while for the episode of high political risks, the weighted sum hovers between 50 - 60 percent benchmark (see Figure 6). This implies that there were even more periods of very high political risks in the country. Curiously, the interest rate is highest during the period 1992Q2 -1994Q4. This implies that investment will be stifled, and growth will be impeded. The implication for macroeconomic trilemma is that there would be high influx of capital transactions into the country due to portfolio adjustment of the global investors. If this influx of capital transaction exceeds the productive capacity of the economy at that point in time, there would be financial instability.

Consequently, the growth ratio of credit to the private sector to GDP is highest during this period. This suggests that credit expansion is highest during this period. It is an indication that there is high financial instability in this period in Nigeria than any other period under study. Another period of relatively high interest rate in the country is 1991Q1 - 2002Q2. It is observed that there is no financial instability during this period as the growth ratio of credit to the private sector to the GDP is almost lowest during this period. This suggests that the productive capacity of the economy has been able to absorb the influx of financial flows that was necessitated by the increase in interest rate. The growth of money supply is highest between 2007Q3 - 2008Q3. This 
suggests that the monetary authority embarked on expansionary monetary policy during the period of very high political risks. This is also evident during the earlier period of very high political risk (1981Q1 - 1983Q2).

\subsection{Data Stability Condition}

Data stability condition is to ascertain the stationarity or otherwise of the variables included in the model. It also provides an insight into the estimation procedure employed for analyses. In order to avoid misleading results, the data stability test conducted for this study is the ZivotAndrew (2002) unit-root with structural breaks. This is essential to examine the presence of break-points in the variables as a series considered to be non-unit-root but with structural breaks would lead to wrong choice of method of analyses. As detailed in Table 1, it is evident that the variables for estimations of macroeconomic trilemma and central bank behaviour in Nigeria have different break periods and the levels of stationarity also differ. Only the change in the exchange rate, growth of the economy and output gap that are non-unit-root at levels, other variables such as the political risk, interest rate, inflation rate, net export and growth of money supply that are all unit-root at levels. This suggests that the use of deterministic models would not be appropriate for this study. This further justifies the use of the Markov Switching models which can capture different break-point period within a structural analysis in a modeling framework such as this.

\subsection{The Trilemma Constraint and Policy Trade-Off in Nigeria}

As earlier posited, the starting point for a study on investigating the trilemma hypothesis is to ascertain if the trilemma constraint holds and identify the binary choice variables of the triad policy that is optimal for the economy. One decision rule to validate the existence of the trilemma hypothesis and that the trilemma constraint holds is that the estimates as well as the coefficients for these triad policies; when regressed against a constant, should all be positive and must have high goodness-of-fit. Also, the trade-off to determine the binary policy choice, when regressed against one another, must be negatively signed. As detailed in Table 2, it is evident that all the coefficients for the triad policies are positively related to the constant and highly statistically significant; at least, at the 5 percent level. 
Also, the regression estimates to determine the appropriate binary combinations show that, on the one hand, trade-off significantly exists between monetary independence and financial openness (Panel D, Table 2). On the other hand, there is trade-off between exchange rate and monetary independence (Panel C). However, the estimates in Panel B suggests that exchange rate stability (ES) and financial openness (FO) are the binary choices of the triad policy for the Nigerian economy; albeit insignificantly. The implication is that only exchange rate stability and financial openness can be combined at a time in Nigeria while the monetary independence is the policy trade-off. This confirms that the trilemma constraint holds for Nigeria and that the trilemma hypothesis has been validated. From an empirical standpoint, this study conforms to the findings in many country specific studies on the validation of the trilemma hypothesis in most economies.

Studies that obtained these results include Hsing (2013) and Oshikoya (2014). More so, it conforms to the findings in the empirical literature that both exchange rate and financial openness have remained the optimal policy choices for developing economies for at least a decade now. Studies in this category are Sengupta and Sengupta (2013, 2014). This implies that monetary policy becomes an endogenous variable in Nigeria as the central bank has to ensure it sells domestic currency to buy foreign currency in order to avoid the pressure for currency appreciation during the period under consideration. On the other hand, the monetary authority buys domestic currency in order to sell foreign currency so as to avoid the pressure for currency depreciation. This is to ensure exchange rate stability in the country.

The statistically significant trade-off between monetary independence and financial openness in Nigeria is highly instructive. The insight from this is that for the monetary authority in Nigeria to independently determine interest rate in the economy, it must significantly control the flow of capital transactions in and out of the economy. The implication is that sudden withdrawal of short-term capital; known as hot-money, must be avoided and that surge in the quantum of longterm capital must be in tandem with the developmental pace of the economy. In fact, liberalization on capital account transactions must be gradual and sequenced. Otherwise, the injection of additional and withdrawal of excess liquidity by the monetary authority will becomes less effective in driving the growth of the economy. 


\subsection{Estimation of Regime Switching Model with Macroeconomic Trilemma}

When the monetary policy is faced with the effect of macroeconomic trilemma in Nigeria, there are two possible exchange rate regimes viz; managed-float regime and fixed exchange rate regime. This information is gleaned from the fact that State 1 has average exchange rate of 1.925 with 1.160 standard errors while State 2 has average exchange rate of 82.18 with 40.15 standard errors. The implication is that the managed-float regime (State 1) has average exchange rate value that dispersed away from its intrinsic value by 1.160 while the fixed exchange rate (State 2) dispersed widely with 40.148 standard errors but with 82.181 average values. The lagged dependent variable is significant at probability values of 0.012 and 0.084 for the case of managed-float regime; with and without political risk factors respectively. This confirms that exchange rate behaviour is better modeled as a dynamic process.

For the case of fixed exchange rate regime, also, its fitness to Markov Switching dynamic regression model is confirmed. It should be noted that under each of the exchange rate regimes, there is a dichotomy to both the inclusion of political risks factor and without. It is evident that under managed-float regime, all explanatory variables for macroeconomic trilemma do not differ in terms of size and significant. The only exception is the growth process of the Nigerian economy (indicated as rgdp) which, with political risk factor, is significantly negatively related to exchange rate behaviour at the 5 percent level with -0.170 coefficient. Specifically, the political risk is inversely related to the exchange rate movement in Nigeria with -0.159 coefficients with significantly T-statistics value at the 5 percent level with 0.017 probability values. The implication is that an increase in the value of political risk (which simply denotes a reduced political risk) would results in a fall in exchange rate (that is, an appreciation). Therefore, the results show that a lower political risk will engender an exchange rate appreciation in the Nigerian economy.

This is also the case under a fixed exchange rate regime with -4.182 coefficient and 0.000 probability value. Interestingly, though, when the economy is faced with macroeconomic trilemma and the exchange rate regime is fixed, then, the growth of the economy have significant impacts on the exchange rate movement with -127.964 . This suggests that economic growth 
enhances exchange rate appreciation. Also, the growth of money supply has -0.967 coefficients; albeit insignificantly at the 5 percent level. A possible intuition for macroeconomic trilemma here is that with fixed exchange rate regime, increase in monetary growth could create a pressure for currency appreciation. Both the foreign interest rate and net export are positively signed with 9.875 and 0.0003 coefficients respectively. These estimates are significant at the 5 percent level too. The implication is that an increase in the foreign interest rate, which translates to reduced financial openness; consequent upon portfolio adjustment, would lead to pressure for foreign exchange rate devaluation. The positive coefficient of 0.0003 for the net export would significantly create a pressure for exchange rate devaluation under a fixed exchange rate regime; either with or without political risks. This is unlike the case of managed-float regime where the increase in the net export and foreign rate of interest creates pressure for exchange rate appreciation; albeit insignificantly. Table 16 captures the probabilities of transition and durations of persistence of exchange rate movement in Nigeria. The exchange rate is persistent at the managed-float regime to the tune of 96.1 percent but 30.6 percent at the fixed exchange rate regime (Table 4, Panel A).

This indicates that there is a 96.1 percent that the exchange rate regime will be of managed-float in the next quarter if it is currently operating at the managed-float in the current quarter. In fact, the duration of persistence is approximately 26 quarters under the managed-float regime and 1.44 quarters during the fixed exchange rate regime. This is equivalent to four and a half $\left(4^{1} / 2\right)$ years and one (1) quarter of persistence respectively. The cross probabilities of transition suggest that it is much easier to transit from a fixed exchange rate regime to a managed-float regime by 69.4 percent while it is near impossible to transit from managed-float to fixed exchange rate regime by a paltry 3.9 percent chance (Panel B, Table 4). However, when political risk is considered, the probabilities of persistence dropped to 93.9 percent and 20.8 percent respectively while the cross probabilities of persistence increased to 6.1 percent from a managed-float to a fixed exchange rate regime and 79.2 percent from a fixed exchange rate regime to a managed-float regime. The conclusion here is that political risk speeds up the transition of regime switching but reduced the degree of persistence of the exchange rate regimes. 


\subsection{Conclusion and Recommendation}

The study showed that the trilemma constraints hold for the Nigerian economy as the trilemma hypothesis was validated. The appropriate binary choice variables to counteract the effect of the trilemma hypothesis are the combination of both exchange rate stability and financial openness. This implies that the monetary authority in Nigeria cannot crave for autonomy in the face of macroeconomic trilemma. With this, it implies that money supply becomes an endogenous monetary policy in Nigeria as it would be used as the variable of adjustment to stabilize the exchange rate in the economy. The implication from this is that to stabilize exchange rate in Nigeria, the monetary authority has to continually intervene through the use of money supply. . There are two regimes of exchange rate in Nigeria and these are identified as the fixed exchange rate and managed-float regimes. With the exchange rate being the policy variable of the monetary authority, political risk was found insensitive to the regimes of exchange rate.

In conclusion, political risk faced by the economy is less important in determining the behaviour of the monetary authority in the face of macroeconomic trilemma than even the binary choices of the triad policies made. However, foreign interest rate and net export were sensitive to the type of exchange rate regime. It leads to exchange rate appreciation, and significantly so, under a managed-float regime but results in exchange rate depreciation given a fixed exchange rate regime. Stemming from this conclusion, the followings are recommended. First, the endogenous determination of the money supply indicates that there would be economic prosperity when there is effective exchange rate management and barriers on cross-border financial capital flows are sequenced. Also, political institutions should be put in check such that impulses from these institutions would not affect the dynamics of macroeconomic trilemma and, consequently, the behavior of the Central Bank of Nigeria. In order to counteract the negative effects of foreign interest rate and net exports, government should create enabling environment to reduce the risk premium on investments and stimulate aggregate demand in the economy.

\section{*Availability of data and material}

The data for this study are available on request. 


\section{*Competing interests}

It is instructive to note that there is no competing interesting for this study. The two authors with corresponding email addresses provided here are the contributed to the completion of this manuscript.

\section{*Funding}

The African Economic Research Consortium (AERC) is greatly appreciated for creating the research funds towards the completion of my (Dr. T. O. Ayinde) Ph.D. programme; product of which is this research paper.

\section{*Authors' contributions}

Dr. T.O. Ayinde reviewed the literature and also undertakes estimations of empirical analyses. He also concludes and proffer policy suggestions. Prof. A.S. Bankole was my Ph.D. supervisor and his efforts in the conceptualization of this manuscript and contributions to identify the gap in existing literature that this study contributed to cannot go unnoticed.

\section{*Authors' information (optional)}

Professor Abiodun S., Bankole was the Dean of the Faculty of Economics and Management Sciences at the University of Ibadan, Nigeria. He has wide ranging experience in teaching, research and consultancy with national and international funding agencies and organisations.

Dr. T.O. Ayinde is the Head, Department of Economics, Fountain University, P.M.B. 4491, OkeOsun, Osogbo, Nigeria. He is an Alumni of the African Economic Research Consortium (AERC) during his Collaborative Ph.D. Progamme (CPP) at the University of Ibadan, Nigeria.

\section{*Acknowledgements}

These authors appreciate the research platforms and sponsorship created by the African Economic Research Consortium (AERC) to present this work at the different fora of research and intellectual capacities. 


\section{REFERENCES}

Aizenman, J. and Ito, H. 2014. Living with the trilemma constraint: relative trilemma policy divergence, crises and output losses for developing countries. Journal of International Money and Finance, Vol. 49, Pp. 28 - 51.

Aizenman, J., and Ito, H. 2012a. Trilemma policy convergence patterns and output volatility. North American Journal of Economics and Finance, Vol. 23, Pp. 269 - 285.

Aizenman, J. and Sengupta, R. 2012b. The Financial trilemma in China and comparative analysis in India. UCSC and the NBER, USA and IFMR, India.

Aizenman, J. Chinn, M.D., and Ito, H. 2011. Surfing the waves of globalization: Asia and financial globalization in the context of the trilemma. Journal of Japanese International Economies, Vol. 25, Pp. $290-230$.

Aizenman, J., Chinn, M.D., and Ito, H. 2008. Assessing the emerging global financial architecture: measuring the trilemma's configurations over time. NBER Working Paper Series, No. 14533.

Alesina, A., and Roubini, N. 1992. Political cycles in OECD economies. The Review of Economic Studies, Vol. 59(4), Pp. $663-688$.

Bankole, A., and Ayinde, T.O. 2014. Capital accounts liberalization and foreign direct investment in Nigeria - A Bound-Testing Approach. Botswana Journal of Economics, Vol. 12, Pp. $14-32$.

Bartolini, L., and Drazen, A. 1997. Capital account liberalization as a signal. American Economic Review, 87(1), Pp. 138 - 154.

Baele, L., Ferrando, A., Hordahl, P., Krylova, E., and Monnet, C. 2004. Measuring financial integration in the euro Area. ECB occasional paper, European central bank, Frankfurt.

Beckmann, J., Ademmer, E., Belke, A. and Schweickert, R. 2017. The political economy of the impossible trinity. European Journal of Political Economy, Vol. 47, Pp. 103 - 123.

Cheung, Y.W. and Qian, X. 2009. Hoarding of international reserves: Mrs Machlup's wardrope and the jonesses. Review of International Economics, Vol. 17, No. 4, Pp. 777 - 801.

Chinn, M.D., and Ito, H. 2008. A new measure of financial openness. Journal of Comparative Policy Analysis, Vol. 10, No. 3, Pp. 309 - 322.

Chinn, M.D., and Meredith, G. 2004. Monetary policy and long-run uncovered interest parity. IMF Staff Papers, Vol. 51, No. 3, Pp. $409-430$.

Dooley, M., Folkerts-Landau, D., and Garber, P. 2013. An essay on the revived Bretton woods System, NBER Working Paper Series, 9771.

Dooley, M.P., and Isard, P. 1980. Capital controls, political risks and deviations from interest rate parity. The Journal of Political Economy, 88(2), P. 370.

Feldstein, M., and Horioka, C. 1980. Domestic savings and international capital flows. The Economic Journal, Vol. 90, No. 358, Pp. 314 - 329.

Fisher, I. 1930. The Theory of Interest. MacMillan, New York.

Fleming, J.M. 1962. Domestic financial policies under fixed and under floating exchange rates. Staff Papers, International Monetary Fund, Vol. 9 (November), Pp. $369-79$.

Frankel, J., Schmukler, S.L., and Serven, L. 2004. Global transmission of interest rates: Monetary independence and currency regime. Journal of International Money and Finance, Vol. 23, No. 5, Pp. $701-703$.

Frankel, J. 1995. How Well Do Foreign Exchange Market Function: Might a Tobin Tax Help? Oxford University Press.

Gan, P. 2014. The precise form of financial integration: empirical evidence for selected 
Asian countries. Economic Modelling, Vol. 42, Pp. 208 - 219.

Georgiadis, G. and Mehl, A. 2015. Trilemma, Not dilemma: financial globalization and monetary policy effectiveness. Federal Reserve Bank of Dallas, Globalization and Monetary policy Institute, Working Paper No. 222.

Goh, S.K., and McNown, S. 2015. Examining the exchange rate regime - monetary policy autonomy nexus: evidence from Malaysia. International Review of Economics and Finance, Vol. 35, Pp. 292 - 303.

Goldfeld, S.M. and Quandt, R.E. 1973. A markov model for switching regression. Journal of Econometrics, Vol. 1, Pp. $3-16$.

Golomejic, Z. R. 2011. Coordination between the monetary and public debt management policies in Crotia. Croatia National Bank, Zegreb, Croatia.

Guidolin, M. 2011a. Markov-switching in portfolio choice and asset pricing models: a survey. In advances in econometrics: Vol 273 - Missing Data Methods: Time Series Methods and Applications ed. D.M. Drukker, 87 - 178, Bingley, Emerald, UK.

Guidolin, M. 2011b. Markov-switching models in empirical finance: in advances in econometrics: Vol 273 - Missing Data Methods: Time Series Methods and Applications ed. D.M. Drukker, 1 - 86, Bingley, Emerald, UK.

Hadiwibowo, Y., and Komatsu, M. 2011. Trilemma and macroeconomic policies under different financial structures in Indonesia. Journal of Asian Economics, Vol. 22, Pp. 302 -310 .

Hamilton, J.D. 1999. Time Series Analysis, Princeton University Press.

Hamilton, J.D. 1989. A new approach to economic analysis of non-stationary time series and business cycle. Econometrica, Vol. 57, Pp. 357 - 384.

Hamilton, J.D. 1990. Analysis of time-series subject to regime changes. Journal of Econometrics, Vol. 45, Pp. $39-70$.

Haque, N.U., and Montiel, P.J. 1991. Capital mobility in developing countries: some empirical tests. World Development, Vol. 19, Pp. 139 - 198.

Hsing, Y. 2013. Study of the trilemma policies and their impact on inflation, growth and volatility for Brazil. Global Journal of Management and Business Research Finance, Vol. XIII, Issue IV, Version 1.0, Pp. 27 - 32.

Ihnatov, I. and Capraru, B. 2014. The trilemma policies and macroeconomic volatility in central and eastern Europe. Procedia Economics and Finance, Vol. 15, Pp. 853 - 857.

Jamilov, R. 2013. Capital mobility in the Caucasus. Economic Systems, Vol. 37, Pp. 155 -170.

Kaldor, N. 1980. Monetarism and UK monetary policy. Cambridge Journal of Economics, Vol. 4, Pp. $293-318$.

Lavoie, M., and Yan, X. 2004. The compensation thesis vs. the Mundell-Fleming model in a fixed exchange rate regime. Department of Economics, University of Ottawa, Ontario.

Mandilaras, A.S. 2015. The international policy trilemma in the post-Bretton woods era. Journal of Macroeconomics, Vol. 44, Pp. 18 - 32.

Masih, A.M.M. 2005. Macroeconomic policy trilemma in open economies: Which policy option is ideally suited to the Malaysian context? Jurnal Pengurusan, Vol. 24, Pp. 3 - 26.

McKinnon, R.I. 1973. Money and Capital in Economic Development. Washington DC, Brookings Institution.

Mills, T., and Wang, P. 2006. Modelling regime shift behaviour in Asian real interest rates. Economic Modelling, Vol. 23, No. 6, Pp. $952-966$.

Montiel, P. 1994. Capital mobility in developing countries: some measurement issues and 
empirical estimates. World Bank Economic Review, Vol. 8, No. 3, Pp. $311-350$.

Mundell, R.A. 1963. Capital mobility and stabilization policy under fixed and flexible exchange rates. Canadian Journal of Economics and Political Science, Vol. 29, Pp. 475 -85 .

Muth, J.F. 1961. Rational expectations and the theory of price movements. Econometrica, Vol. 29, No. 3, Pp. $315-335$.

Nordhaus, W.D. 1975. The political business cycle. Review of Economic Studies, 42(2), Pp. $169-190$.

Nurkse, R. 1947. International monetary policy and the search for economic stability. Havard Economic Studies, Pp. 72 - 103.

Park, B., Buntaine, M. and Buch, B. 2017. Why developing countries get stuck with weak institutions and how foreign actors can help. Brookings Institution Reports.

Pasricha, G. 2010. Good for America, as far as it went. Financial Times, March 7.

Phelps, E.S. 1967. Phillips curves, expectations of inflation and optimal unemployment over time. Economica, Vol. 34, No. 135, Pp. $254-281$.

Popper, H., Mandilaras, A., and Bird, G. 2013. Trilemma stability and international macroeconomic archetypes. European Economic Review, Vol. 64, Pp. 181 - 193.

Quandt, R.E. 1972. A new approach to estimating switching regressions. Journal of the American Statistical Association, Vol. 67, Pp. $306-310$.

Quinn, D., Schindler, M., and Toyoda, A.M. 2011. Assessing measures of financial openness and integration. IMF Economic Review, Vol. 59, No. 3, Pp. 488 - 522.

Reade, J. J., and Volz, U. 2011. Chinese monetary policy and the dollar peg. Discussion Paper 35. Free University, Berlin, School of Business and Economics.

Rizavi, S.S., Naqvi, B., and Rizv, S.K.B. 2011. Global and regional financial integration of Asian stock markets. International Journal of Business and Social Science, Vol. 2, No. 9.

Schularik, M., and Ward, F. 2015. Dilemma or trilemma? Global financial cycles and exchange rate regimes, 1870 - 2013. EHES Conference, Pisa.

Sengupta, R. and Cheung, Y. 2011. Accumulation of reserves and keeping with the jonesses: the case of LATAM economies. International Review of Economics and Finance, Vol. 20, Pp. $19-31$.

Shambaugh, J.C. 2004. The effect of fixed exchange rates on monetary policy. Quarterly Journal of Economics, Vol. 119, No. 1, Pp. $300-351$.

Shaw, E. 1973. Financial deepening in economic development. New York: Oxford University Press.

Vo, X.V. 2005. International financial integration and economic growth: a panel analysis. The Business Review, Vol. 3, No. 3.

Wicksell, K. 1898. Interest and Prices, translated by R.F. Kahn (New York: M.Kelly Publishers, 1965).

Woo, W.T., and Nasution, A. 1989. The political economy factors in policymaking in Sachs, J.F., Collins, M. 1989, Developing Country Debt and Economic Performance, University of Chicago Press, Vol. 3. Downloaded at http://www.nber.org/chapters/c9023, Pp. 56 67.

Yabara, M. 2012. Capital market integration: progress ahead of the east African community monetary union. IMF Working Paper, WP/12/18. 
Figure 1: Macroeconomic Trilemma and Financial Trilemma with Binary Policy Choices

\begin{tabular}{|l|l|l|l|}
\hline \multicolumn{4}{|c|}{ Panel 1a: Macroeconomic Trilemma } \\
\hline Triad Policies & Policy Choice I & Policy Choice II & Policy Choice III \\
\hline Monetary Independence & Yes & Yes & No \\
\hline Financial Integration & Yes & No & Yes \\
\hline Exchange Rate Stability & No & Yes & Yes \\
\hline Source: Author with insights from Mundell (1963) and Fleming (1962) \\
\hline \multicolumn{3}{|c|}{ Panel 1b: Financial Trilemma } \\
\hline Triad Policies & Policy Choice I & Policy Choice II & Policy Choice III \\
\hline National Financial Policy & Yes & Yes & No \\
\hline Financial Integration & Yes & No & Yes \\
\hline Financial Stability & No & Yes \\
\hline Source: Ito (2014) & & Yes \\
\hline
\end{tabular}

Figure 2: The Mechanics of Macroeconomic Trilemma and Central Bank Behaviour

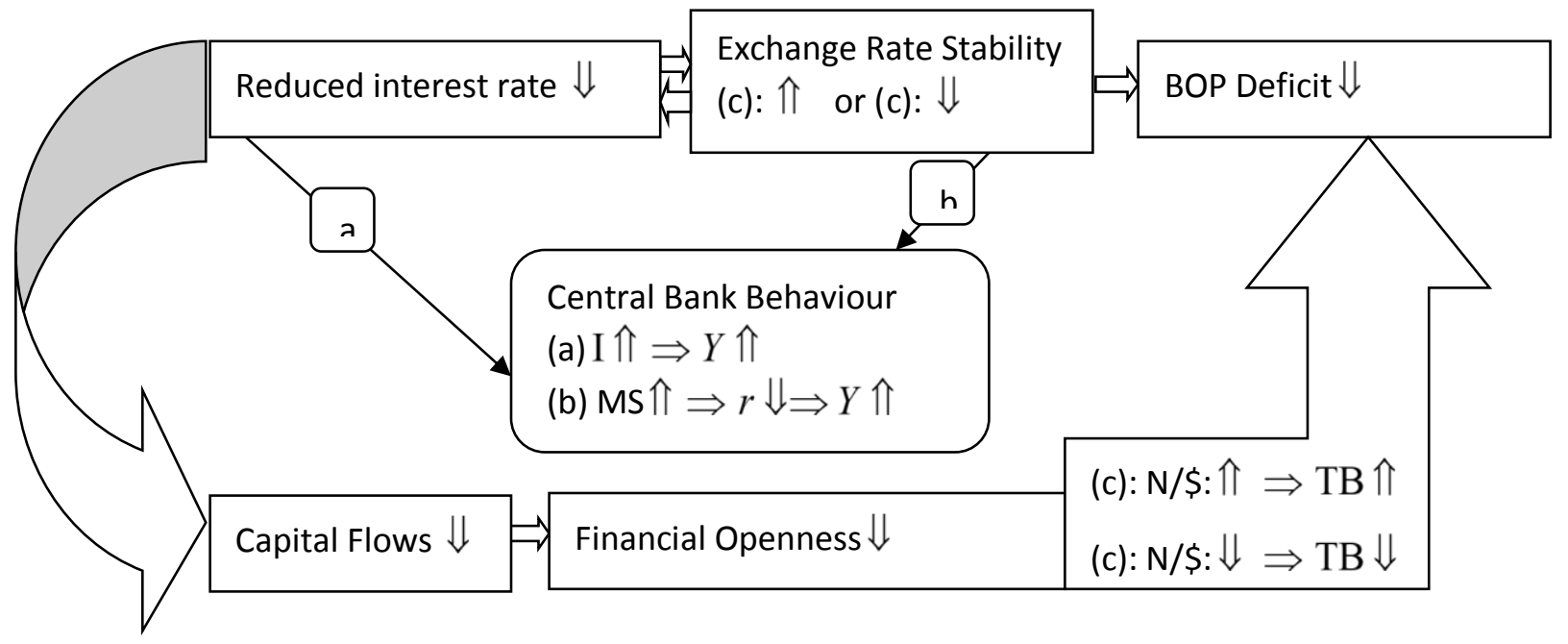


Figures

\begin{tabular}{|l|l|l|l|}
\hline \multicolumn{5}{|c|}{ Panel 1a: Macroeconomic Trilemma } \\
\hline Triad Policies & Policy Choice I & Policy Choice II & Policy Choice III \\
\hline Monetary Independence & Yes & Yes & No \\
\hline Financial Integration & Yes & No & Yes \\
\hline Exchange Rate Stability & No & Yes & Yes \\
\hline Source: Author with insights from Mundell (1963) and Fleming (1962) \\
\hline \multicolumn{2}{|c|}{ Panel 1b: Financial Trilemma } & \\
\hline Triad Policies & Policy Choice I & Policy Choice II & Policy Choice III \\
\hline National Financial Policy & Yes & Yes & No \\
\hline Financial Integration & Yes & No & Yes \\
\hline Financial Stability & No & Yes & Yes \\
\hline Source: Ito (2014) & & & \\
\hline
\end{tabular}

Figure 1

Macroeconomic Trilemma and Financial Trilemma with Binary Policy Choices 


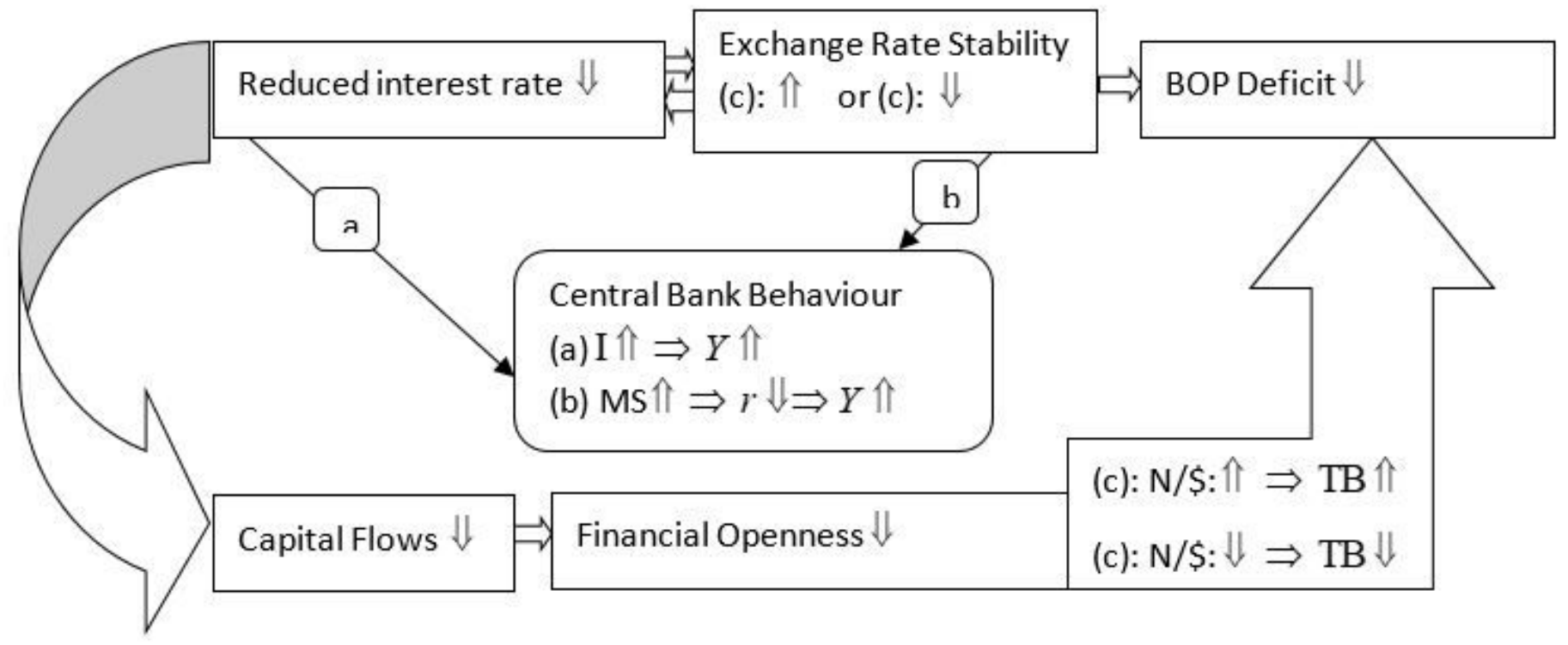

Figure 2

The Mechanics of Macroeconomic Trilemma and Central Bank Behaviour 